(c) American Dairy Science Association, 2003.

\title{
Concentrations of Progesterone in Milk of Cows Administered an Intravaginal Progesterone Insert
}

\author{
J. R. Chenault, ${ }^{\star}$ R. E. Hornish, $†$ Y. C. Anderson, $\dagger$ L. F. Krabill, $\dagger$ \\ J. F. Boucher, ${ }^{\star}$ and M. J. Prough† \\ *Product Development-Food Animal and \\ †Pre-clinical Development, \\ Pharmacia Animal Health, \\ Kalamazoo, Ml 49001
}

\begin{abstract}
Milk from pregnant cows contains concentrations of progesterone (P4) considered safe for human consumption. The objective of this study was to determine if concentrations of $\mathrm{P} 4$ in milk during administration of an intravaginal progesterone insert (CIDR insert) are less than concentrations of $\mathrm{P} 4$ in milk associated with pregnancy. Results have implications for human use of milk from cows receiving CIDR inserts. Holstein cows ( $\mathrm{N}=64 ;>40$ and $<150 \mathrm{~d}$ after calving) were administered $25 \mathrm{mg}$ of $\mathrm{PGF}_{2 \alpha}$ i.m. (study d 0 ) and 20 cows detected in estrus from 2 to $4 \mathrm{~d}$ later were assigned randomly to either control $(\mathrm{N}=10$; no further treatment) or CIDR insert ( $\mathrm{N}=10 ; 1.38 \mathrm{~g}$ of $\mathrm{P} 4)$ inserted on study d 17 ( $14 \pm 1 \mathrm{~d}$ after estrus) and removed $7 \mathrm{~d}$ later. Composite milk samples were collected contemporaneously from each of the 20 estrous cycling cows and from 10 pregnant cows ( $\geq 60$ and $\leq 220 \mathrm{~d}$ of gestation) twice daily from study d 17 to 27 . Concentrations of P4 in defatted milk samples were quantified using a validated radioimmunoassay. Mean logs of areas under the curve of concentrations of $\mathrm{P} 4$ from the afternoon on study $\mathrm{d}$ 17 through the afternoon on study d 27 were $3.05 \mathrm{ng}$ $\mathrm{day} / \mathrm{ml}$ for control, $3.33 \mathrm{ng}$ day/ml for CIDR insert, and $3.81 \mathrm{ng}$ day/ml for pregnant cows. Therefore, increased $\mathrm{P} 4$ due to pregnancy was $0.76 \mathrm{ng}$ day/ml (3.81-3.05), whereas the increase in P4 due to CIDR insert was only $0.28 \mathrm{ng}$ day/ml (3.33 - 3.05). Applying a 95\% confidence interval to $0.28 \mathrm{ng}$ day $/ \mathrm{ml}$ provided an upper value of $0.70 \mathrm{ng} \mathrm{day} / \mathrm{ml}$, lower than the increase due to pregnancy. Because milk from pregnant cows is considered safe for human consumption, it follows that milk from cows administered CIDR inserts should also be considered safe, based on concentrations of $\mathrm{P} 4$.
\end{abstract}

Received September 6, 2002.

Accepted December 2, 2002.

Corresponding author: John R. Chenault; e-mail: John.R. Chenault@Pharmacia.com.
(Key words: intravaginal progesterone insert, concentrations of progesterone in milk, dairy cow)

Abbreviation key: AUC = area under the curve, CIDR insert = EAZI-BREED CIDR Cattle Insert, CIDR B insert $=$ EAZI-BREED CIDR B Cattle Insert, $\mathbf{D P C}=$ Diagnostic Products Corporation, $\mathbf{L O Q}=$ limit of quantification; $\mathbf{P 4}$ = progesterone, $\mathbf{Q C}=$ quality control.

\section{INTRODUCTION}

The EAZI-BREED CIDR Cattle Insert (CIDR insert; intravaginal insert containing $1.38 \mathrm{~g}$ of progesterone [P4]; Pharmacia Animal Health, Kalamazoo, MI) and the EAZI-BREED CIDR B Cattle Insert (CIDR B insert; intravaginal insert containing $1.9 \mathrm{~g}$ of $\mathrm{P} 4$; Pharmacia Animal Health, Kalamazoo, MI) are marketed in many countries of the world. These products are used to induce estrous cyclicity in anestrous cows and prepubertal heifers (Fike et al., 1997; Xu et al., 2000; Lucy et al., 2001), to synchronize the return to estrus of previously inseminated cattle (Macmillan and Peterson, 1993; Macmillan and Burke, 1996; Chenault et al., 2003), and as one component of treatment regimens administered to synchronize estrus of cattle (Macmillan and Peterson, 1993; Ryan et al., 1995; 1999; Xu et al., 1996; Lamb et al., 2001; Lucy et al., 2001). To synchronize the return to estrus, in general, inserts are administered $14 \pm 1 \mathrm{~d}$ after insemination and removed $7 \mathrm{~d}$ later. For synchronization of estrus and induction of estrous cyclicity inserts are administered for 7 or $8 \mathrm{~d}$. However, when inserts are used for synchronization of estrus an injection of $\mathrm{PGF}_{2 \alpha}$ should be administered to obtain maximal synchronization of estrus. This $\mathrm{PGF}_{2 \alpha}$ can be administered either at the time the insert is removed or 1 or $2 \mathrm{~d}$ before removal.

No published studies could be found addressing concentrations of $\mathrm{P} 4$ in milk following administration of CIDR inserts (1.38 $\mathrm{g}$ of $\mathrm{P} 4)$. One published study was found that addressed the effect of CIDR B insert administered to ovariectomized cows for $9 \mathrm{~d}$ on the concentrations of P4 in whole milk (Van Cleeff et al., 1992). The 
concentration of $\mathrm{P} 4$ in milk was $3.6 \mathrm{ng} / \mathrm{ml}$ before CIDR $\mathrm{B}$ administration, increased in the first milk sample after insert administration, peaked at $8.8 \mathrm{ng} / \mathrm{ml}$ on the second day after administration and decreased thereafter to a low of $1.7 \mathrm{ng} / \mathrm{ml} 8 \mathrm{~d}$ after administration.

The objective of this study was to quantify the concentrations of $\mathrm{P} 4$ in milk from cows before, during, and after administration of CIDR inserts $14 \pm 1 \mathrm{~d}$ after estrus to aid in the assessment of the safety of this milk for human consumption. The underlying assumption of this study was that concentrations of P4 in milk from pregnant cows are safe for human consumption. Under this assumption, milk from cows administered CIDR inserts would be considered safe for human consumption if the increase in concentrations of $\mathrm{P} 4$ in milk resulting from administration of a CIDR insert was less than increases in concentrations of $\mathrm{P} 4$ in milk resulting from pregnancy. To test this assumption the concentrations of $\mathrm{P} 4$ also were determined in milk from untreated estrous cycling cows and pregnant cows in addition to estrous cycling cows administered CIDR inserts. This is the first report addressing concentrations of $\mathrm{P} 4$ in milk before, during, and after administration of CIDR inserts to estrous cycling cows and to address the potential impact on human food safety of the milk produced during administration of CIDR inserts in dairy cows.

\section{MATERIALS AND METHODS}

\section{Animal Phase}

This study was conducted under authorization of Investigational New Animal Drug Authorization 6224 (Center for Veterinary Medicine, Food and Drug Administration). The animal phase of the study was conducted in compliance with Good Laboratory Practices standards with the exception that daily milk weights were collected retrospectively from the on-farm record system.

The study was conducted in a commercial dairy in southwest MI during the months of February and March, 2002. Commercial grade, Holstein cows were housed in a freestall barn with a centralized feed alley equipped with head lockups. Cows were managed and fed according to normal procedures of the dairy. Feed, consisting of a total mixed ration, was available ad libitum.

Cows that were $>40$ and $<150 \mathrm{~d}$ post calving and known to be not pregnant were subjected to a physical examination by the herd veterinarian. Cows without clinical signs of respiratory disease, clinical mastitis, metritis, pyometra, chronic or severe lameness, and uterine adhesions detected during this physical examination were considered as potentially eligible for enrollment. Using these criteria, 64 cows were identified to be potentially eligible for enrollment. To allow collection of milk samples over a minimal number of days, estrus was synchronized in these 64 cows by administration of a single IM injection of $25 \mathrm{mg}$ of $\mathrm{PGF}_{2 \alpha}(5 \mathrm{ml}$ LUTALYSE Sterile Solution, Pharmacia Animal Health, Kalamazoo, MI) on study d 0 . These 64 cows were observed for signs of estrous behavior and 20 cows defined as being in estrus on 2 to $4 \mathrm{~d}_{\text {after }} \mathrm{PGF}_{2 \alpha}$ were assumed to be estrous cycling and were enrolled in the study. Estrus was defined either as observed to stand when mounted by a herd mate (standing estrus; primary definition) or as observed displaying two or more of the following ancillary signs of estrus: riding activity, a clear, thin vaginal mucus discharge, roughened hair on tail head, dirty sides, off feed or restlessness. Cows observed in standing estrus $(n=18)$ or with two or more ancillary signs of estrus $(n=2)$ were not inseminated but were assigned randomly in replicates within estrous code, to each of two groups: Control or CIDRinsert cows. Control cows received no further treatment. CIDR-insert cows received intravaginal administration of a CIDR insert on study d $17(14 \pm 1 \mathrm{~d}$ after estrus) within $1 \mathrm{~h}$ following the a.m. milking. CIDR inserts were removed $7 \mathrm{~d}$ later (study d 24; $21 \pm 1$ $\mathrm{d}$ after estrus) within $1 \mathrm{~h}$ following the a.m. milking. Administration of CIDR inserts $14 \pm 1 \mathrm{~d}$ after estrus and a 7-d administration period were selected specifically to mimic use of CIDR inserts for synchronization of the return to estrus of previously inseminated dairy cows (Chenault et al., 2003). However, for the study reported herein, cows were not inseminated at the enrollment estrus. This allowed an estimate of the contribution by the CIDR inserts to concentrations of progesterone in milk during and following the administration period without any confounding due to pregnancy.

The dairy heard health record system was used to list lactating cows that were $\geq 60$ and $<150$ d of gestation (n $=166)$ and $\geq 150$ and $\leq 220 \mathrm{~d}$ of gestation $(\mathrm{n}=122)$. From these cows a random selection of 17 cows $<150$ $\mathrm{d}$ of gestation and 27 cows $\geq 150 \mathrm{~d}$ of gestation was recorded. The herd veterinarian examined cows in the order recorded and the first five cows within each gestation group that were confirmed pregnant and without clinical signs of disease were enrolled. The five cows selected for the earlier stage of pregnancy group ranged from 86 to $142 \mathrm{~d}$ of gestation on study d 5 and the five cows selected for the later stage of pregnancy group ranged from 155 to $193 \mathrm{~d}$ of gestation on study d 5 .

Cows in the milking string $(\mathrm{n}=72)$ that contained the 30 cows assigned to the study were milked twice daily, beginning at 4:30 a.m. and 2:30 p.m. The mean daily milk yields over the interval from study d 6 to 27 were $29.0 \mathrm{~kg} / \mathrm{d}$ for control, $31.4 \mathrm{~kg} / \mathrm{d}$ for CIDR insert and $23.1 \mathrm{~kg} / \mathrm{d}$ for pregnant cows. A composite milk sam- 
ple was collected once daily (a.m. milking) from each cow in the Control and CIDR insert groups on study $\mathrm{d}$ 6 to 16 and then twice daily on study d 17 to 27 . A composite milk sample was collected twice daily from each pregnant cow on study d 17 to 27 , contemporaneously with non-pregnant cows in the other two treatment groups. Composite milk samples were collected by placing a subsample of approximately $45 \mathrm{ml}$ of the entire milking for each individual cow into a $50 \mathrm{ml}$ polypropylene centrifuge tube containing approximately $45 \mathrm{mg}$ of potassium dichromate $(0.1 \%)$ as a preservative. The tubes were inverted several times to dissolve the potassium dichromate. Milk samples were kept on ice during transfer to the laboratories of Pharmacia Animal Health.

\section{Laboratory Phase}

The laboratory phase of the study was conducted in compliance with Good Laboratory Practices standards. Milk samples were stored at 2 to $8^{\circ} \mathrm{C}$ until processed to remove milk fat. Milk fat was removed within $24 \mathrm{~h}$ after collection by centrifugation at approximately 1500 $\times g$ for 10 min under refrigerated conditions $\left(2\right.$ to $\left.8^{\circ} \mathrm{C}\right)$. The fat layer was then gently pushed to one side and the skim milk was carefully aspirated with a pipette. These de-fatted milk preparation conditions were based on those described by Nachreiner et al. (1992) and were carefully followed for all samples in order to avoid temperature-dependent variation in de-fatted milk $\mathrm{P} 4$ concentrations. After centrifugation, the de-fatted samples were stored frozen at $<-15^{\circ} \mathrm{C}$ until assayed.

The Coat-A-Count Progesterone RIA kit (Diagnostic Products Corporation [DPC], Los Angeles, CA) was used to assay the de-fatted milk samples. This commercial kit was developed and validated by DPC to assay P4 in human serum and plasma. In order to assay P4 in bovine milk, one modification was made to the kit as provided by DPC; the $\mathrm{P} 4$ calibrators (standards) provided in the kit were discarded because they were made using human serum and were replaced with standards prepared in charcoal stripped bovine milk. Standards were made with P4 (Pharmacia Corporation, Kalamazoo, MI; 98.1\% purity) at the same concentrations of $\mathrm{P} 4$ as the standards provided with the kit; 0, 0.1, 0.5, 2, 10,20 , and $40 \mathrm{ng} / \mathrm{ml}$. Standards were prepared using a milk sample that had been collected from a bulk tank and subsequently defatted and treated with charcoal to remove endogenous P4 (Sharpe and Cooper, 1984). Using these standards, the assay procedure recommended by DPC was followed.

Fortified de-fatted milk samples were used to determine the accuracy, precision, sample stability and parallelism of the modified assay. Precision and accuracy were assessed using a pooled de-fatted milk sample fortified with $0,0.1,0.5,1,2,10$, and $20 \mathrm{ng}$ of $\mathrm{P} 4 / \mathrm{ml}$ that were assayed in five runs. Parallelism was addressed using four de-fatted milk samples with relatively high endogenous concentrations of $\mathrm{P} 4$ that were diluted serially $(1: 2,1: 4,1: 8,1: 16,1: 32$, and 1:64) using charcoal-stripped milk and then assayed for P4.

Milk sample stability was assessed using pooled defatted milk samples containing low concentrations of endogenous $\mathrm{P} 4$. These samples were collected from cows in estrus or within $3 \mathrm{~d}$ following estrus that were fortified with $\mathrm{P} 4$ at concentrations of $0,0.5,1$, and $10 \mathrm{ng} /$ $\mathrm{ml}$. Samples were subjected to bench-top, freeze-thaw and long-term stability protocols. Bench-top stability was assessed by allowing samples to remain at room temperature for 0 or $4 \mathrm{~h}$ before assay. This represented the range in time that samples were expected to be at room temperature before assay. Freeze-thaw stability was assessed by subjecting samples to zero, one, two, or three freeze-thaw cycles. Long-term stability was assessed by storing samples for $0,24,29$, and $59 \mathrm{~d}$ at -15 to $-30^{\circ} \mathrm{C}$.

The pooled defatted milk sample with low endogenous concentration of $\mathrm{P} 4$ also was used for quality control (QC) samples. The concentration of endogenous P4 in this pooled sample was determined using calibration standards prepared in de-fatted, charcoal-stripped milk and was $0.075 \pm 0.01 \mathrm{ng} / \mathrm{ml}( \pm \mathrm{SD} ; \mathrm{n}=10)$. This pooled sample was fortified with exogenous $\mathrm{P} 4$ at concentrations of $0.5,5.0$, and $15.0 \mathrm{ng} / \mathrm{ml}$. These fortified samples were anticipated to cover the range of concentrations of $\mathrm{P} 4$ expected in the milk samples from cows on study, allowing that some samples could fall below the limit of quantification (LOQ). The observed concentrations for the fortified QC samples were corrected for the endogenous concentration of $\mathrm{P} 4$ in the pooled sample $(0.075 \mathrm{ng} / \mathrm{ml})$.

Defatted milk samples were analyzed for P4 concentrations using the basic assay procedure recommended by DPC with the exceptions as noted above. Study samples, calibration standards, and QC samples were run in duplicate. The QC samples at all concentrations were assayed near the beginning of the daily run, after approximately every 50 milk samples (100 assay tubes) and at the end of the run. The $\mathrm{QC}$ samples were included for decisions to accept or reject a given assay. An assay was to be accepted if at least $80 \%$ of the QC samples were within $20 \%$ of the expected concentrations.

Statistical Analyses. Recovery of P4 from fortified samples of milk subjected to bench-top, long-term and freeze-thaw stability studies was analyzed using analysis of variance (SAS/STAT, 1990, 1997). The main effects for the analysis of variance were fortification level, 
time of storage, or number of freeze-thaw cycles and the interaction between fortification level and time of storage. Trend analysis also was performed over time or cycles. The variances for recovery of $\mathrm{P} 4$ at each time point or freeze-thaw cycle were compared using Hartley's F-max test.

The standard curves of each assay run were fitted by a weighted, non-linear regression analysis using a fourparameter logistic model (Rodbard and Hutt, 1974) and SAS Procedure NLIN (SAS/STAT, 1990, 1997). The weighting factor was $1 /[1+(0.1 \times$ counts per minute $)]$, which decreased as the counts per minute increased. The non-linear regression was performed using the Gauss-Newton method.

Concentrations of $\mathrm{P} 4$ in the milk samples were backcalculated using the parameters from the regression analysis (SAS/STAT, 1990, 1997). The acceptability of the regression and the standard curve was monitored by visually inspecting a plot of the standard curve and examining the mean back-calculated concentrations of the standards to determine if they were within $20 \%$ of the expected concentrations.

For parallelism, the slopes of the standard curves were compared to slopes of the dilution curves using a $t$ test based on the difference in slope for the curves being compared. All slopes and associated asymptotic standard errors were calculated using non-linear regression analysis and the model used for calculating the standard curves as described immediately above.

The LOQ was determined experimentally using fortified samples with acceptable accuracy and precision.

The area under the curve (AUC) for concentrations of P4 in milk was used as the primary decision variable. All milk samples collected had P4 concentrations determined; however, only the milk samples from the p.m. milking of study d 17 (first sample after CIDR insert administration) through the p.m. milking of study d 27 were included in the calculation of the AUC. Progesterone concentrations in milk samples collected from control and CIDR insert cows on study d 6 to 16 were used to verify that those cows were at the expected days of the estrous cycle during the study. Cows were expected to have low concentrations of $\mathrm{P} 4(<1 \mathrm{ng} / \mathrm{ml})$ on study d 6 ( 2 to $4 \mathrm{~d}$ of the estrous cycle) and increasing concentrations to luteal levels by study d 16 (12 to $14 \mathrm{~d}$ of the estrous cycle). Visual observation of the mean daily P4 profiles before treatment administration revealed that the mean concentration of $\mathrm{P} 4$ in milk was greater in the control than in the CIDR insert treatment. Therefore, the mean concentration of P4 in milk on study d 15,16 and the a.m. milking on study $d 17$ was used as a covariate to adjust for differences between these two experimental groups before initiation of treatment. A $\log$ transformation of the AUC data was performed to help stabilize the variance. For statistical analyses, the arithmetic average of the $\log (\mathrm{AUC})$ was used for the pregnant cows, whereas the mean of the covariate adjusted Log(AUC) was used for the control and CIDR insert groups.

The hypotheses tested was "is the increase in the concentration of $\mathrm{P} 4$ in milk due to administration of the CIDR insert less than the increase due to pregnancy" and may be presented as:

$\mathrm{H}_{0}: \mu_{\text {CIDR }}-\mu_{\text {Control }} \geq \Delta$

$\mathrm{H}_{1}: \mu_{\text {CIDR }}-\mu_{\text {Control }}<\Delta$

Where $\mu_{\mathrm{x}}$ is the true population milk P4 $\log$ (AUC) mean for treatment $\mathrm{x}$ and $\Delta$ is an acceptability threshold. For this study, $\Delta$ was set as the difference between the mean $\log (\mathrm{AUC})$ of pregnant and cycling control groups $\left(\right.$ Mean $\left._{\text {Pregnant }}-\operatorname{Mean}_{\text {Control }}=\Delta\right)$. The $\Delta$ was considered to be an acceptable threshold because milk from pregnant cows is considered safe for human consumption. Therefore, increased concentrations of $\mathrm{P} 4$ observed in milk from pregnant cows, relative to that in milk from non-pregnant, estrous-cycling cows, is an acceptable increase. An upper 95\% confidence limit on the difference between the mean $\log (\mathrm{AUCs})$ of CIDR and cycling control cows $\left(\mathrm{Mean}_{\mathrm{CIDR}}-\mathrm{Mean}_{\mathrm{Control}}=\mathrm{D}\right)$ was used to test the hypothesis. If the upper confidence limit on $\mathrm{D}$ is less than $\Delta$, then $\mathrm{H}_{0}$ can be rejected. Analysis of covariance was used for this analysis (SAS/STAT, 1999). The model included the fixed effects of experimental group (excluding the pregnant cow group), the average $\mathrm{P} 4$ concentration from study $\mathrm{d} 15,16$, and the a.m. milk of study d 17 as a covariate and the random effect of study day the cow was first observed in estrus (study d 2, 3, or 4).

\section{RESULTS AND DISCUSSION}

\section{Assay Validation}

The LOQ of the milk P4 assay was determined to be $0.1 \mathrm{ng} / \mathrm{ml}$. The coefficients of variation for repeatability (intraassay) and reproducibility (interassay) were 7.7 and $9.5 \%$, respectively. Calculated recoveries of $\mathrm{P} 4$ from pooled samples fortified with $0,0.1,0.5,1,2,10$, and $20 \mathrm{ng} / \mathrm{ml} \mathrm{P} 4$ ranged from 85.5 to $108.6 \%$ of expected concentrations and overall averaged $94.0 \%$ with a standard deviation of $8.9 \%$.

The mean recoveries of $\mathrm{P} 4$ (corrected for endogenous P4) after 0 and $4 \mathrm{~h}$ at room temperature were 105.5 and $104.2 \%$, respectively. The analysis of variance showed no difference due to time $(P=0.85)$ or any interaction between time and fortification level $(P=$ 0.87). These results imply that milk samples may be left at room temperature for $4 \mathrm{~h}$ before assay without any loss of $\mathrm{P} 4$. 
The mean recoveries of $\mathrm{P} 4$ (corrected for endogenous P4) after $0,1,2$, and 3 freeze-thaw cycles were 99.2, $101.9,100.8$, and $99.1 \%$, respectively. The analysis of variance did not detect any difference due to cycles $(P=$ 0.76 ) or any interaction between cycles and fortification level $(P=0.09)$. Also, no trends were detected over the course of the freeze-thaw cycles $(P \geq 0.33)$. These data showed no indication of a change in concentration of P4 in fortified milk samples when subjected to up to three freeze-thaw cycles.

The mean recoveries of $\mathrm{P} 4$ (corrected for endogenous P4) after $0,24,29$, and $59 \mathrm{~d}$ of storage at -15 to $-30^{\circ} \mathrm{C}$ were $100.4,95.4,98.2$, and $106.2 \%$, respectively. The analysis of variance detected no difference due to days of storage $(P=0.22)$ or any interaction between days of storage and fortification level $(P=0.58)$. Also, no trends in recoveries were detected over the storage period $(P \geq 0.15)$. Based on these data, milk samples can be stored in the freezer $\left(-15\right.$ to $\left.-30^{\circ} \mathrm{C}\right)$ for up to $59 \mathrm{~d}$ before being assayed without the loss of $\mathrm{P} 4$.

For the parallelism protocol the dilution curves of all samples were parallel to the appropriate standard curve, because no differences in slopes were detected among the curves $(P \geq 0.12)$.

At least $80 \%$ of the $\mathrm{QC}$ samples run in assays evaluating milk samples from cows in the study were within $20 \%$ of the expected concentrations. Therefore, all assay runs were accepted.

\section{Concentrations of Progesterone in Milk}

Concentrations of $\mathrm{P} 4$ in de-fatted milk from individual cows in the control, CIDR insert and pregnant cow treatments are presented in Figures 1, 2, and 3, respectively. Visual evaluation of the pattern of concentrations of P4 in milk of individual cows revealed that two cows had aberrant concentrations of P4 in milk during the pretreatment period. Cow 8904 (control) had concentrations of P4 in milk greater than $1 \mathrm{ng} / \mathrm{ml}$ on study d 6, 7, and 8 when concentrations were expected to be below $1 \mathrm{ng} / \mathrm{ml}$. Concentrations of P4 in milk from that cow decreased to less than $1 \mathrm{ng} / \mathrm{ml}$ on study d 17 to 25 when concentrations were expected to be above $1 \mathrm{ng} /$ $\mathrm{ml}$ (Figure 1). This cow was enrolled into the study based on ancillary signs of estrus and was not observed in standing estrus. Based on the profile of $\mathrm{P} 4$ concentrations in the milk samples, it was concluded that this cow was not in estrus on study d 3 when she was selected for enrollment. Therefore, milk P4 data from this cow were not included in statistical analyses. Cow 8917 was enrolled based on observed standing estrus and was assigned to receive a CIDR insert. This cow had $\mathrm{P} 4$ concentrations in milk below $0.1 \mathrm{ng} / \mathrm{ml}$ for all samples taken on study d 6 to 17 before CIDR insert administration
(Figure 2). Concentrations of P4 in milk increased to $1.74 \mathrm{ng}$ day/ml in the first milking after CIDR Insert administration and remained in a range of $0.73 \mathrm{ng} / \mathrm{ml}$ to $1.56 \mathrm{ng} / \mathrm{ml}$ during the 7 -d CIDR insert administration period, compared to the range in mean concentrations of P4 for all other cows with CIDR inserts on these study d of $2.16 \mathrm{ng} / \mathrm{ml}$ to $4.26 \mathrm{ng} / \mathrm{ml}$. The concentration of $\mathrm{P} 4$ in milk for this cow fell below $0.10 \mathrm{ng} / \mathrm{ml}$ immediately following removal of the CIDR insert. Apparently, this cow was either anestrous or anovulatory during the study; therefore, milk P4 data from this cow were not included in the statistical analyses.

Treatment means of $\mathrm{P} 4$ concentrations in defatted milk for all treatment groups are plotted in Figure 4 (covariate adjusted for CIDR insert treated and untreated estrous-cycling cows). The concentration of P4 increased, on average, about $1 \mathrm{ng} / \mathrm{ml}$ in the first milk sample following CIDR insert administration. At each sample period during the administration period the average concentration of $\mathrm{P} 4$ in milk from cows administered CIDR inserts was greater than that observed in milk from untreated estrous cycling cows. Using analysis of covariance, a difference was not detected $(P=$ 0.127 ; Table 1 ) between the control estrous cycling cows and cows receiving CIDR inserts in $\log (\mathrm{AUC})$ of concentrations of $\mathrm{P} 4$ in milk over the interval from the p.m. milk sample on study d 17 to the p.m. milk sample on study d 27. However, this study was not designed with sufficient power to detect the difference that was anticipated to occur between these two treatment groups. Concentrations of $\mathrm{P} 4$ in milk declined immediately following removal of the CIDR inserts on study d 24 and were similar to concentrations of P4 in milk of untreated estrous cycling cows for all remaining samples (Figure 4).

Table 1. Analysis of covariance for log of the area under the curve [Log(AUC)] of concentrations of progesterone (P4) in milk over the interval of the p.m. milk sample on study d 17 to the p.m. milk sample on study d 27.

\begin{tabular}{|c|c|c|c|}
\hline \multirow[b]{2}{*}{ Source } & \multicolumn{3}{|c|}{$\begin{array}{c}\log (\mathrm{AUC}) \\
(\mathrm{ng} \text { day/ml) }\end{array}$} \\
\hline & Variance & $\mathrm{df}^{1}$ & $P$-Value \\
\hline Day of Estrus ${ }^{2}$ & 0.0000 & 2 & \\
\hline Pre $^{3}$ & . & 1 & 0.037 \\
\hline Treatment $^{4}$ & . & 1 & 0.127 \\
\hline Error & 0.2247 & 13 & \\
\hline
\end{tabular}

${ }^{1} \mathrm{df}=$ degrees of freedom.

${ }^{2}$ Day of Estrus was the random effect of when a cow was first seen with signs of estrus (study d 2,3, or 4).

${ }^{3}$ The mean milk P4 concentration on study d 15, 16 and the a.m. milking on study d 17 was used as the covariate.

${ }^{4}$ Includes only the CIDR insert and untreated control treatment groups. One-sided $P$-value. 

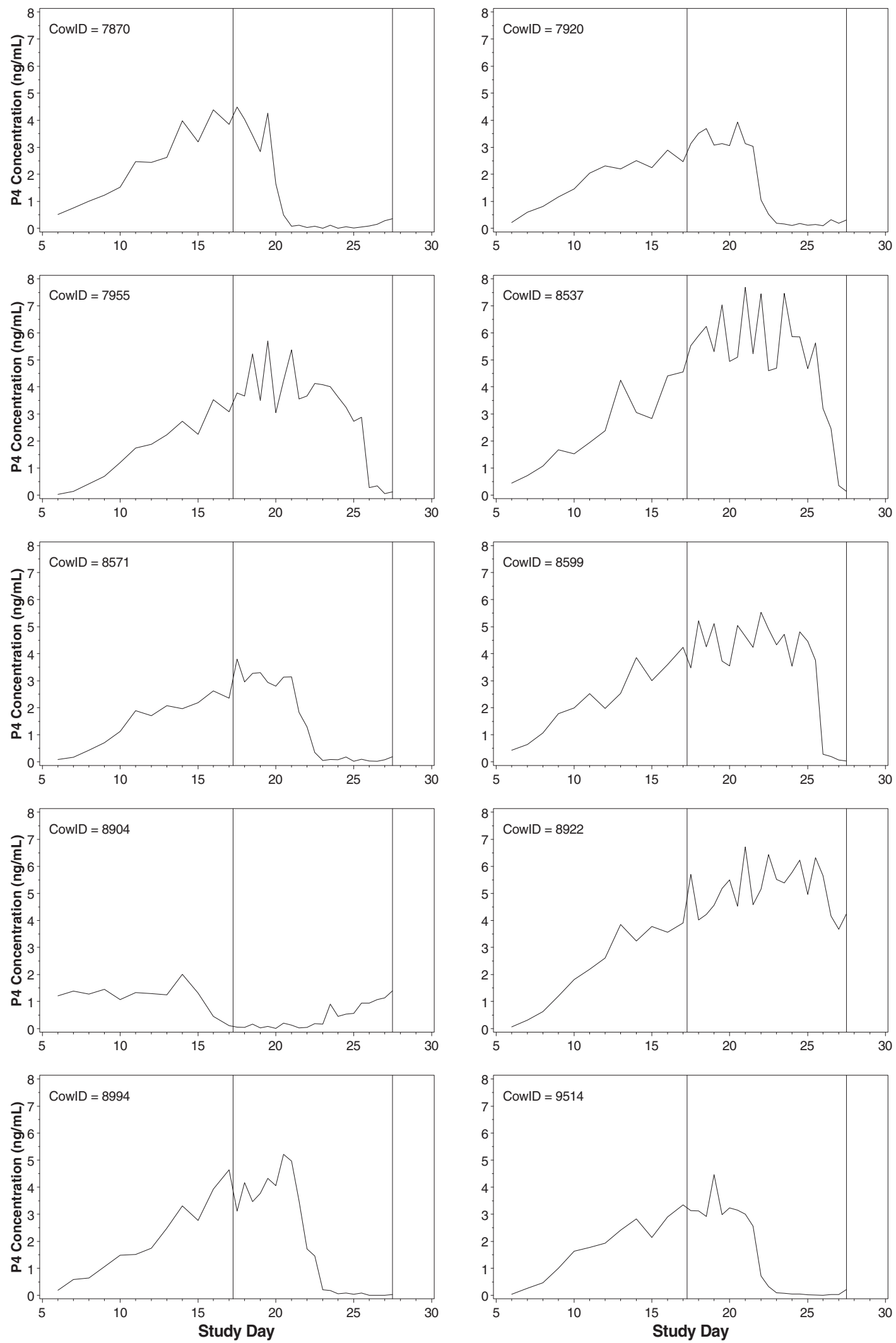

Figure 1. Concentrations of progesterone (P4) in de-fatted milk for individual untreated control cows. Data between vertical lines were used in the calculation of the area under the curve for statistical analysis; Study d $17=14 \pm 1 \mathrm{~d}$ after estrus. 

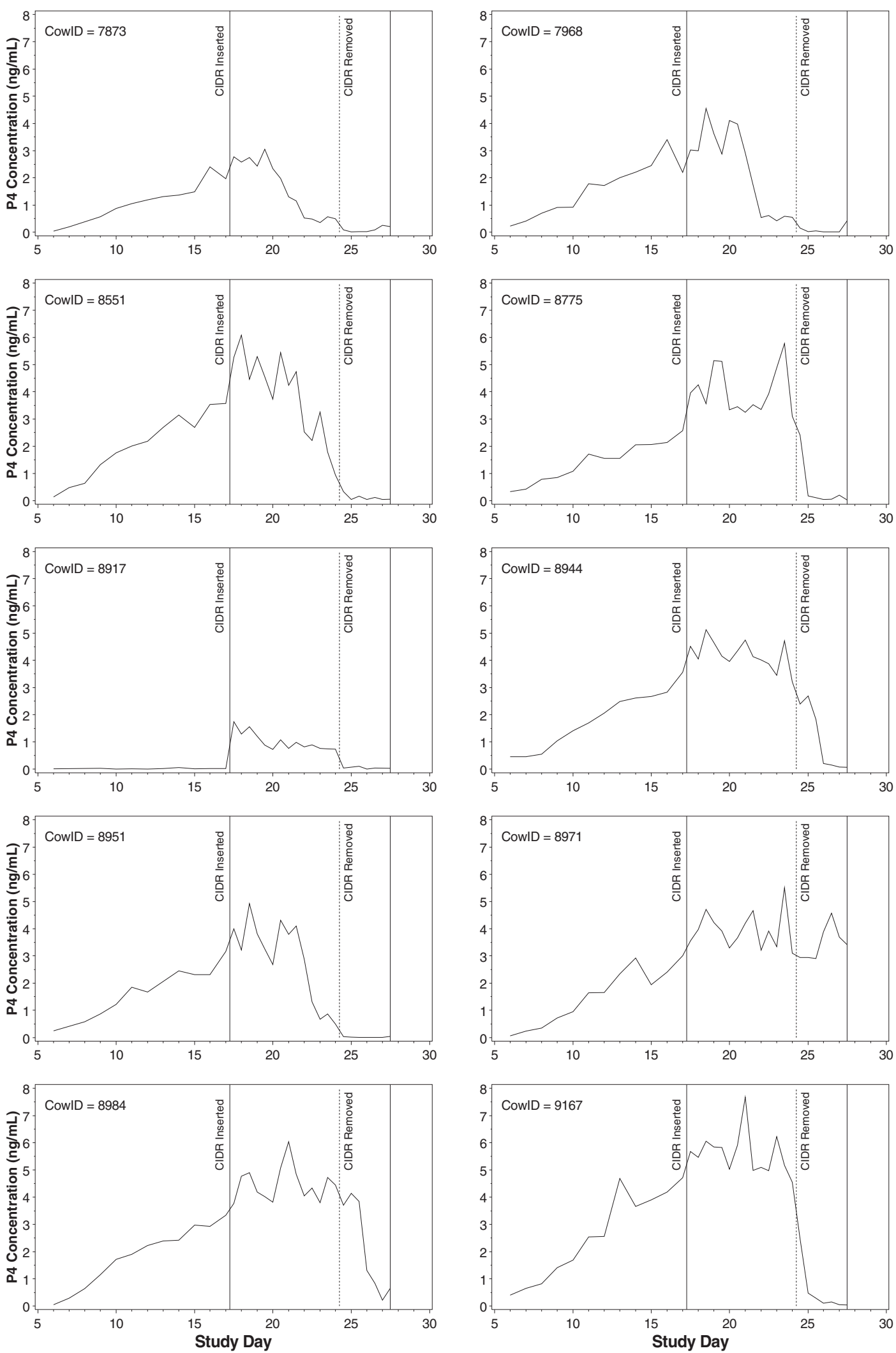

Figure 2. Concentrations of progesterone (P4) in de-fatted milk for individual cows administered a CIDR insert. Data between solid vertical lines were used in the calculation of the area under the curve for statistical analysis; Study d $17=14 \pm 1 \mathrm{~d}$ after estrus. 

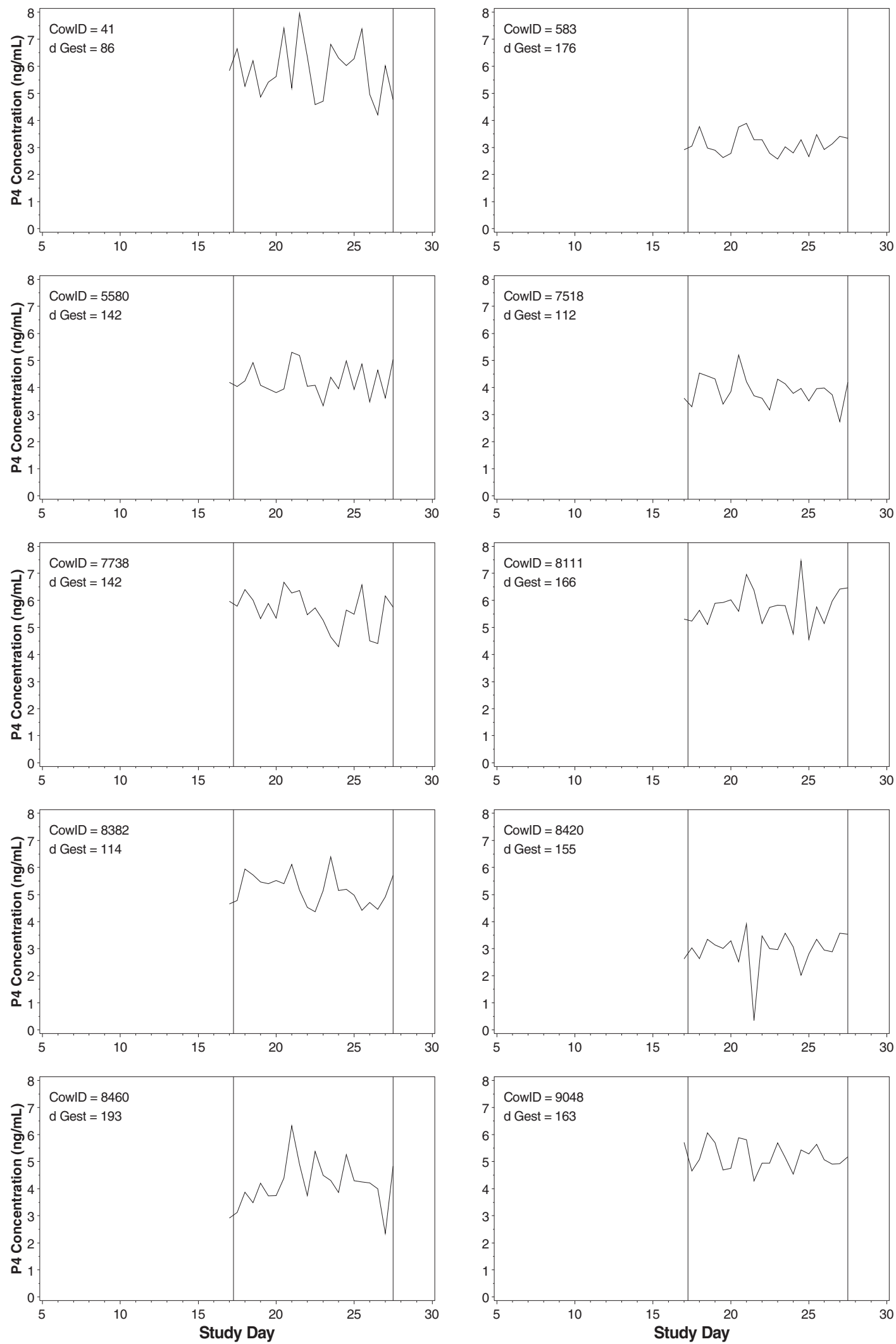

Figure 3. Concentrations of progesterone (P4) in de-fatted milk from individual pregnant cows. Data between vertical lines were used in the calculation of the area under the curve for statistical analyses; d Gest = day of gestation on Study d 5. 


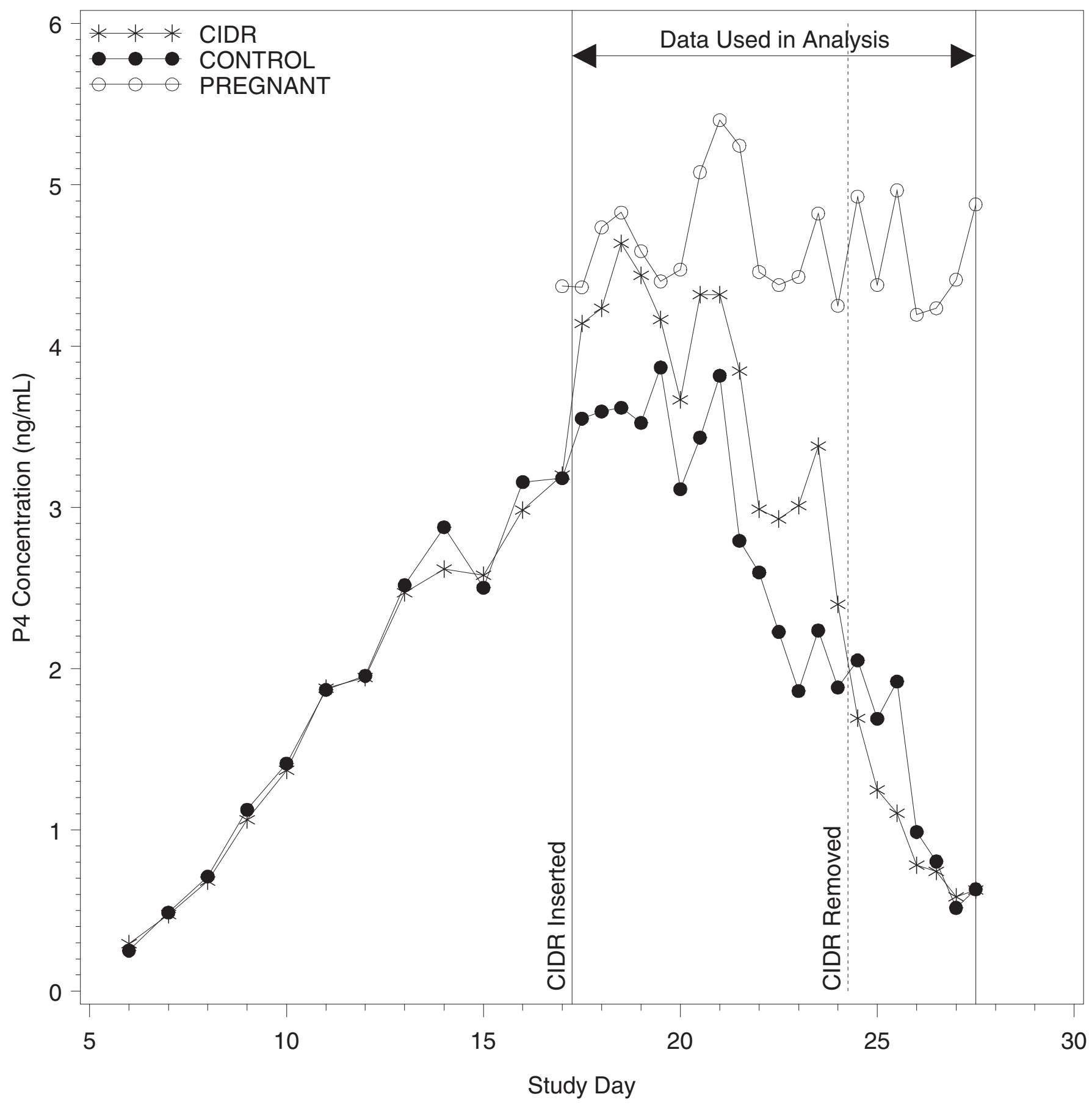

Figure 4. Average concentrations of progesterone (P4) over time in de-fatted milk from untreated estrous cycling cows $(\mathrm{CONTROL} ; \mathrm{n}=$ 9), estrous cycling cows administered a CIDR insert (CIDR; $n=9$ ) and untreated pregnant cows (PREGNANT; $n=10)$ with concentrations for cycling cows (control and CIDR) adjusted for pre-treatment differences. Study d 17 was $14 \pm 1 \mathrm{~d}$ after estrus.

The average Log(AUC) for concentrations of P4 in milk samples from pregnant cows over the interval from the p.m. sample on study d 17 to the p.m. sample on study d 27 was $3.81 \mathrm{ng}$ day $/ \mathrm{ml}$ (Table 2). The average Log(AUC) for the control group over this interval was
$3.05 \mathrm{ng}$ day $/ \mathrm{ml}$. The difference $(\Delta)$ between the pregnant and control cows was calculated as $3.81-3.05=$ $0.76 \mathrm{ng}$ day $/ \mathrm{ml}$. This $\Delta$ represents an acceptable increase in the concentration of $\mathrm{P} 4$ in milk. The hypothesis under test was to determine if the increase in concen- 
Table 2. Log of the area under the curve [Log(AUC); ng day/ml] of the progesterone concentrations in milk during the interval from the p.m. milk sample on study d 17 to the p.m. sample on study d 27 .

\begin{tabular}{|c|c|c|c|c|c|c|}
\hline & Mean Log(AUC) (SE) & & $\Delta^{2}$ & $\mathrm{D}^{3}(\mathrm{SE})$ & $\mathrm{UCL}^{4}$ & Reject $\mathrm{H}_{0}^{5}$ \\
\hline $\begin{array}{l}\text { Pregnant } \\
\text { cows }\end{array}$ & $\begin{array}{l}\text { CIDR insert } \\
\text { treated cows }^{1}\end{array}$ & $\begin{array}{l}\text { Untreated } \\
\text { control cows }\end{array}$ & & & & \\
\hline $3.81(0.08)$ & $3.33(0.16)$ & $3.05(0.16)$ & 0.76 & $0.28(0.24)$ & 0.70 & YES \\
\hline
\end{tabular}

tration of $\mathrm{P} 4$ in milk, due to administration of the CIDR insert, was significantly less than this $\Delta$. The mean Log(AUC) for the CIDR insert group was $3.33 \mathrm{ng}$ day/ $\mathrm{ml}$ and the increase (D) due to CIDR administration was $0.28 \mathrm{ng}$ day/ml (3.33 - 3.05). Applying a 95\% upper confidence interval to this difference resulted in a value of $0.70 \mathrm{ng}$ day $/ \mathrm{ml}$. Because $0.70 \mathrm{ng}$ day $/ \mathrm{ml}$ is less than $0.76 \mathrm{ng}$ day $/ \mathrm{ml}$ the null hypothesis was rejected. Therefore, the use of the CIDR insert resulted in an increased concentration of $\mathrm{P} 4$ in milk that was less $(P<0.05)$ than the increase that resulted due to pregnancy.

Assuming year round calving, an average of $120 \mathrm{~d}$ in milk at conception, a 60-d dry period, and gestation length of $285 \mathrm{~d}$, in the average dairy herd approximately one third of lactating cows would be estrous cycling and two thirds of lactating cows would be pregnant. Therefore, the majority of cows contributing to the milk supply have concentrations of P4 in milk greater than that in milk of estrous cycling cows administered a CIDR insert for $7 \mathrm{~d}$ with administration $14 \pm$ $1 \mathrm{~d}$ after insemination. Because, at any given point in time, CIDR inserts would be administered for synchronization of the return to estrus in only a small percentage of the population of milking cows within a herd, this use of CIDR inserts in commercial dairy herds will have a minimal impact on the overall concentrations of $\mathrm{P} 4$ in milk in the dairy bulk tank.

\section{CONCLUSIONS}

When CIDR inserts were administered for $7 \mathrm{~d}$ beginning on d $14 \pm 1$ after estrus, concentrations of $\mathrm{P} 4$ in de-fatted milk from CIDR insert treated cows were numerically higher than that observed in de-fatted milk from untreated estrous cycling cows. However, over the 10-d interval, consisting of the 7-d CIDR insert administration period and $3 \mathrm{~d}$ after insert removal, a statistically significant difference was not detected in the AUC of concentrations of P4 in defatted milk for these two treatment groups. Increases in the concentrations of P4 in de-fatted milk, due to administration of a CIDR insert were significantly less than increases in concentrations of $\mathrm{P} 4$ in de-fatted milk resulting from pregnancy as measured by differences in the AUC over the 10-d interval consisting of the 7-d CIDR insert administration period and the $3 \mathrm{~d}$ following removal. Therefore, because milk from pregnant cows, which had the highest concentrations of $\mathrm{P} 4$, is considered safe for human consumption, it is concluded that the milk from cows administered a CIDR insert also is safe.

\section{ACKNOWLEDGMENTS}

The authors acknowledge the extensive effort and expertise provided by the following Pharmacia Animal Health personnel for collection of milk samples and other activities conducted during the animal phase of the study: Thomas D. Cox, Tamalyn F. Flook, Philip J. Cutshaw and Joni L. Cutshaw. The authors also acknowledge Bernard Annen and Kevin Nye of the Halbert Dairy for their support and for coordinating all animal-phase activities.

\section{REFERENCES}

Chenault, J. R., J. F. Boucher, K. J. Dame, J. A. Meyer, and S. L. Wood-Follis. 2003. Intravaginal Progesterone Insert to Synchronize Return to Estrus of Previously Inseminated Dairy Cows. J. Dairy Sci. 86:2039-2049.

Fike, K. E., M. L. Day, E. K. Inskeep, J. E. Kinder, P. E. Lewis, R. E. Short, and H. D. Hafs. 1997. Estrus and luteal function in suckled beef cows that were anestrus when treated with an intravaginal device containing progesterone with or without a subsequent injection of estradiol benzoate. J. Anim. Sci. 75:2009-2015.

Lamb, G. C., J. S. Stevenson, D. J. Kesler, H. A. Garverick, D. R. Brown, and B. E. Salfen. 2001. Inclusion of an intravaginal progesterone insert plus $\mathrm{GnRH}$ and prostaglandin $\mathrm{F}_{2 \alpha}$ for ovulation control in postpartum suckled beef cows. J. Anim. Sci. 79:2253-2259.

Lucy, M. C., H. J. Billings, W. R. Butler, L. R. Ehnis, M. J. Fields, D. J. Kesler, J. E. Kinder, R. C. Mattos, R. E. Short, W. W. Thatcher, R. P. Wettemann, J. V. Yelich, and H. D. Hafs. 2001. Efficacy of an intravaginal progesterone insert and an injection of $\mathrm{PGF}_{2 \alpha}$ for synchronizing estrus and shortening the interval to pregnancy in postpartum beef cows, peripubertal beef heifers, and dairy heifers. J. Anim. Sci. 79:982-995.

Macmillan, K. L., and A. J. Peterson. 1993. A new intravaginal progesterone releasing device for cattle (CIDR-B) for estrous synchroni- 
zation, increasing pregnancy rates and the treatment of postpartum anoestrus. Anim. Repro. Sci. 33:1-25.

Macmillan, K. L., and C. R. Burke. 1996. Effects of estrous control on reproductive efficiency. Anim. Repro. Sci. 42:307-320.

Nachreiner, R. F., S. J. Oschmann, L-E. Edqvist, and J. I. Richards. 1992. Factors affecting skim milk progesterone assay results. Am. J. Vet. Res. 53:1085-1089.

Ryan, D. P., S. Snijders, H. Yaakub, and K. J. O'Farrell. 1995. An evaluation of estrous synchronization programs in reproductive management of dairy herds. J. Anim. Sci. 73:3687-3695.

Ryan, D. P., J. A. Galvin, and K. J. O'Farrell. 1999. Comparison of oestrous synchronization regimens for lactating dairy cows. Anim. Repro. Sci. 56:153-168.

Rodbard, D., and D. Hutt. 1974. Statistical Analysis of Radioimmunoassays and Immunometric (Labeled Antibody) Assays. Pages 165-192 in RIA and Related Procedures in Medicine. International Atomic Energy Agency, Vienna.

SAS/STAT User's Guide: Statistics. Version 6, Fourth Edition, 1990. SAS Institute, Inc., Cary, NC.
SAS/STAT Software: Changes and Enhancements through Release 6.12, 1997. SAS Institute, Inc., Cary, NC.

SAS/STAT User's Guide: Statistics. Version 8, 1999. SAS Institute, Inc., Cary, NC.

Sharpe, R. M., and I. Cooper. 1984. Intratesticular secretion of a factor(s) with major stimulatory effects on Leydig cell testosterone secretion in vitro. Mol. Cell Endocrinol. 37:159-168.

Van Cleeff, J., M. C. Lucy, C. J. Wilcox, and W. W. Thatcher. 1992. Plasma and milk progesterone and plasma LH in ovariectomized lactating cows treated with new or used controlled internal drug release devices. Anim. Reprod. Sci. 27:91-106.

Xu, Z. Z., L. J. Burton, and K. L. Macmillan. 1996. Reproductive performance of lactating dairy cows following oestrus synchronization with progesterone, oestradiol and prostaglandin. N.Z. Vet. J. 44:99-104.

Xu, Z. Z., L. J. Burton, S. McDougall, and P. D. Jolly. 2000. Treatment of noncycling lactating dairy cows with progesterone and estradiol or with progesterone, $\mathrm{GnRH}$, prostaglandin $\mathrm{F}_{2 \alpha}$, and estradiol. J. Dairy Sci. 83:464-470. 